\title{
Evidence of accelerated englacial warming in the Monte Rosa area, Switzerland/Italy
}

\author{
M. Hoelzle ${ }^{1}$, G. Darms ${ }^{2}$, M. P. Lüthi ${ }^{3}$, and S. Suter ${ }^{4}$ \\ ${ }^{1}$ Department of Geosciences, University of Fribourg, 1700 Fribourg, Switzerland \\ ${ }^{2}$ Department of Geography, University of Zurich, 8050 Zürich, Switzerland \\ ${ }^{3}$ Laboratory of Hydraulics, Hydrology and Glaciology, ETH Zürich, 8092 Zürich, Switzerland \\ ${ }^{4}$ Department of Construction, Traffic and Environment, Canton of Aargau, 5001 Aarau, Switzerland
}

Received: 13 October 2010 - Published in The Cryosphere Discuss.: 26 October 2010

Revised: 10 March 2011 - Accepted: 11 March 2011 - Published: 21 March 2011

\begin{abstract}
A range of englacial temperature measurements was acquired in the Monte Rosa area at the border of Switzerland and Italy in the years 1982, 1991, 1994, 1995, 1999, 2000, 2003, 2007 and 2008. Englacial temperatures revealed no evidence of warming at the firn saddle of Colle Gnifetti at $4452 \mathrm{~m}$ a.s.l. between 1982 and 1991 , the 1991 to 2000 period showed an increase of $0.05^{\circ} \mathrm{C}$ per year at a depth of $20 \mathrm{~m}$. From 2000 to 2008 a further increase of $1.3^{\circ} \mathrm{C}$ or $0.16^{\circ} \mathrm{C}$ per year was observed, indicating that the amount of infiltrating and refreezing meltwater at Colle Gnifetti has probably increased since 2000 . The measured temperatures give clear evidence of firn warming since 1991. This is confirmed by five existing boreholes with measured temperature down to bedrock, which were drilled in 1982, 1995, 2003 and 2005. All the observed temperature profiles show a slight bending to warmer temperatures in their uppermost part indicating a warming of the firn, which can be related to the observed atmospheric warming in the 20th century. However, the drilling sites on Colle Gnifetti are still located in the recrystallisation-infiltration zone.

A much stronger warming of $6.8^{\circ} \mathrm{C}$ or $0.4^{\circ} \mathrm{C}$ per year was found at locations beneath Colle Gnifetti on Grenzgletscher from 1991 to 2008. This warming is one order of magnitude greater than the atmospheric warming and can be explained only by a strong increase in the latent heat input by infiltrating and refreezing meltwater. The observations indicate that since 1991, an important firn area beneath Colle Gnifetti has already undergone a firn facies change from the recrystallisation-infiltration to the cold infiltration zone due to an increasing supply of surface melt energy.
\end{abstract}

\section{Correspondence to: M. Hoelzle}

(martin.hoelzle@unifr.ch)

\section{Introduction and motivation}

Besides glacier mass balance, firn and ice temperatures of ice bodies can be considered as a key parameter in detecting global warming trends. These temperatures have a sort of a memory function as they register short- and mid-term evolution of the energy balance at the surface. They work as a "natural thermometer with a pronounced long-term memory function". By looking at firn and ice temperature measurements it is possible to assess climate changes in areas where no direct measurements of common climatic parameters are available.

Cold firn and ice in glaciers, ice caps and ice sheets occur when the firn and ice show permanently negative temperatures over the minimum time span of a year. If this is not the case, glaciers are temperate, thus their temperature is at the pressure melting point. Most of the existing cold ice bodies are not cold throughout. These ice bodies are called polythermal (Blatter and Hutter, 1991; Cuffey and Paterson, 2010). According to the mean annual air temperature (MAAT), different temperature zones of the glacier's accumulation area can be distinguished and are called in this study firn facies zones (Benson, 1961; Müller, 1962; Shumskii, 1964):

- the recristallisation zone (Shumskii, 1964) or the dry snow zone (Müller, 1962), where the MAAT is so deep that even in summer no surface melt occurs (e.g., central Antarctica);

- the recristallisation-infiltration zone (Shumskii, 1964) or the percolation zone A (Müller, 1962), where melt is confined to the uppermost annual layer;

Published by Copernicus Publications on behalf of the European Geosciences Union. 
- the cold infiltration zone (Shumskii, 1964) or the percolation zone B (Müller, 1962), where the melt water penetrates through several annual layers of firn; and

- the temperate firn zone, where the melt water warms the firn layers to $0^{\circ} \mathrm{C}$.

Except for the latter zone the above mentioned processes lead to the formation of cold ice in the accumulation area. In addition to the classification above, two different types of cold firn areas can be distinguished. The first type is composed of areas such as summits, crests and very steep slopes, which mainly consists of impermeable ice or very high density firn with many ice layers. The second type contains less inclined slopes or flatter areas with highly permeable firn (Haeberli and Alean, 1985). All of our englacial temperature measurements presented can be assigned to the second type.

Such cold firn and ice areas will play an important role in sea level rise in the next few decades. In these areas the additional energy input from the atmospheric warming is not transformed directly into increased and accelerated melting but rather into a rise in the firn and ice temperatures. This means that the meltwater amount from glacier melt in high Arctic and high Alpine regions could grow considerably in the next years and decades, when large parts of these areas are becoming temperate (i.e., the firn and ice reaches $0^{\circ} \mathrm{C}$ ). This phenomenon will not only accelerate the glacier melt of cold or polythermal valley glaciers in mountain chains, it will above all affect the cold and large ice caps and ice sheets in the Arctic and in the Antarctic regions. Existing englacial temperature measurements within the European Alps can be used as an example to demonstrate such effects.

At the end of the 19th century and into the beginning of the 20th century, it was assumed that all glaciers in the Alps are temperate, although Vallot $(1893,1913)$ had already observed the occurrence of cold firn in the Mont Blanc region at that time. In the 1950s Fisher published several articles about cold firn observations in the Monte Rosa area 1953; 1954; 1955; 1963 as did Haefeli and Brentani (1955) for the Jungfrau area. In the 1970s Lliboutry et al. (1976) and Haeberli (1976) were among the first to systematically investigate the distribution of cold ice and firn in the Alps. In the last 30 years, research activities have increased in the cold high-mountain accumulation areas in the Alps. Many studies have been undertaken in connection with natural hazards and core drillings (Alean et al., 1983; Böhlert, 2005; Darms, 2009; Haeberli and Alean, 1985; Haeberli and Funk, 1985; Laternser, 1992; Lüthi and Funk, 1997, 2000, 2001; Lüthi, 2000; Oeschger et al., 1977; Schwerzmann, 2006; Suter, 1995; Suter et al., 2001; Suter, 2002; Suter and Hoelzle, 2002, 2004; Suter et al., 2004; Vincent et al., 1997, 2007a,b).

Such investigations incorporate several related fields of study such as glacio-chemistry in ice cores, ice flow modelling, mass and energy balance. One additional objective of firn temperature measurements is to monitor and document the influence of the current atmospheric warming on remote high-alpine sites. However, to obtain representative measurements and a reasonable time coverage, it is necessary to find suitable sites which are not disturbed too much by ice flow, melt and high accumulation rates. Currently there are two sites where such measurements have been repeatedly made: Col du Dôme in the Mont Blanc area (Vincent et al. 2007a, 2007b) and Colle Gnifetti in the Monte Rosa area. Colle Gnifetti is a very wind-exposed firn saddle with accumulation rates of 0.3 to $1.2 \mathrm{~m}$ water equivalent per year (Lüthi and Funk, 2000) and the firn-ice transition is depending on the local net snow accumulation and occurs in a depth of around 27 to $43 \mathrm{~m}$ (D. Wagenbach, personal communication, 2010; Lüthi and Funk, 2000).

The shapes and evolution of measured borehole temperature profiles from the recrystallisation-infiltration zone on Colle Gnifetti could be reproduced accurately with a thermomechanically coupled transient heat flow - ice flow model (Lüthi and Funk, 2001). The implementation of such thermal models is made difficult by poorly determined boundary conditions such as large basal heat flux variability (mainly influenced by the complex high mountain topography), horizontal ice/firn advection, changing firn density profiles and the highly variable surface energy balance, which is strongly influenced by the local topography (radiation, wind speed, accumulation, etc.). Many of these influencing factors are site specific. Repeated firn temperature records at selected monitoring sites with suitable glacier geometry are useful for detecting changes in the thermal regime of cold high altitude alpine glaciers. The Swiss Cryospheric Commission of the Swiss Academy of Sciences decided in 2007, based on these findings, to include such firn temperature observations in the existing national glacier observation network. In this paper, the following questions will be addressed:

- has there been a significant warming of the englacial temperatures in the Monte Rosa area during the past 30 years?

- can a possible change in the firn facies be detected?

- is there a uniform warming at all sites or is there a strong spatial variability in the warming?

To answer these questions, unpublished firn and ice temperature measurements from the Monte Rosa area performed between 2003 and 2008 are compared with earlier observations.

\section{Methods}

\subsection{Measuring technique and calibration}

The temperature measurements from 2003 to 2008 were performed using negative temperature coefficient (NTC) thermistors, which show a strong change in resistance with temperature and therefore provided a high sensitivity to small temperature fluctuations. The measured resistances were 


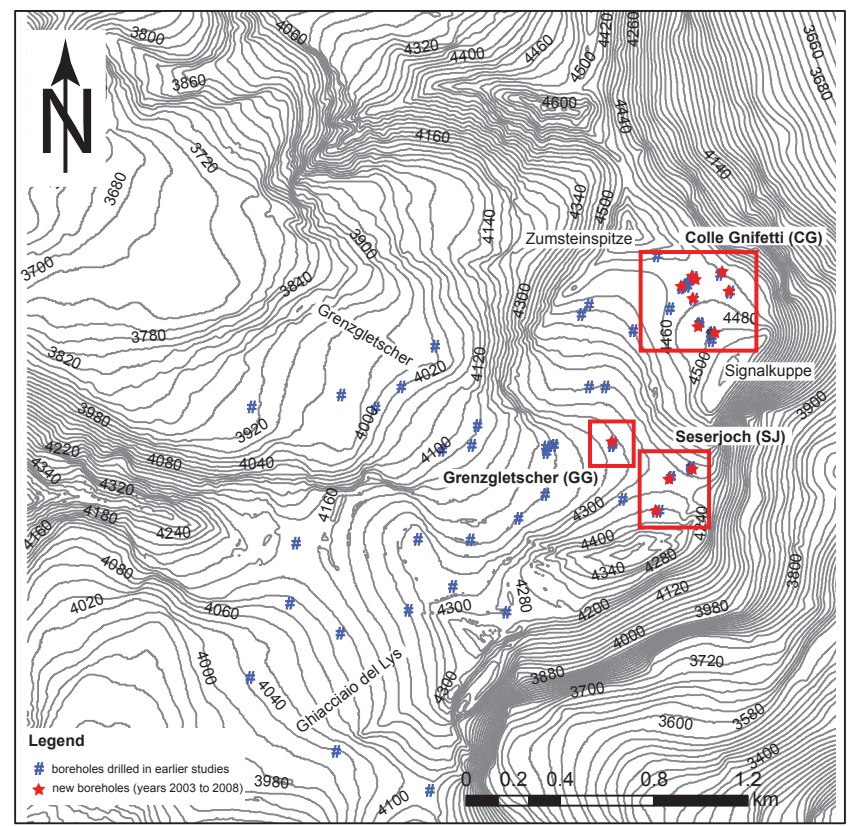

Fig. 1. Location of all borehole sites in the Monte Rosa area. The three insets mark the zoom regions in Figs. 2 and 3.

converted into temperatures using an empirical relationship between resistance and temperature, the so-called SteinhartHart equation. We used three portable thermistor chains with the total length of chain $1=25 \mathrm{~m}$, chain $2=50 \mathrm{~m}$ and chain $3=120 \mathrm{~m}$. The three chains were manufactured in a way to enable if attached in a line, a borehole with a total length of $100 \mathrm{~m}$ to be measured. Single chains allow for more flexibility if shorter boreholes are to be measured. The thermistors on the three chains were placed as follows: chain 1 had a feed line of $20 \mathrm{~m}$ and the thermistors were at $0.2,0.4,0.8,1.2,1.6$, $2,2.5,3,3.5$ and $4 \mathrm{~m}$ depth; chain 2 had a feed line of $25 \mathrm{~m}$ and the thermistors were at $5,7,9,10,11,13,15,20,25$ and $30 \mathrm{~m}$ depth; and chain 3 had a feed line of $60 \mathrm{~m}$ and the thermistors were at 40, 50, 60, 70, 80, 85, 90, 95, 97.5 and $100 \mathrm{~m}$ depth. The thermistor type used was YSI-44031. The thermistor chain was manufactured by Stump Bohr AG in Nänikon, Switzerland. The calibration of the thermistors was done in a large cold ice/water basin at $0{ }^{\circ} \mathrm{C}$. The overall accuracy is determined by several different error possibilities such as the stability of the cold bath during the calibration process, the resolution and accuracy of the data logger, the characteristics of the thermistors and cables and the absolute accuracy of the temperature measuring device. The first three effects mentioned before have determined accuracies in a range of $\pm 0.01 \mathrm{~K}$ and $\pm 0.07 \mathrm{~K}$ according to intense calibration studies performed by Suter (2002) and Lüthi and Funk (2001). Taking into account all possible errors, the absolute accuracy of the thermistor measurements, including all different measurement devices used in the past is estimated to be up

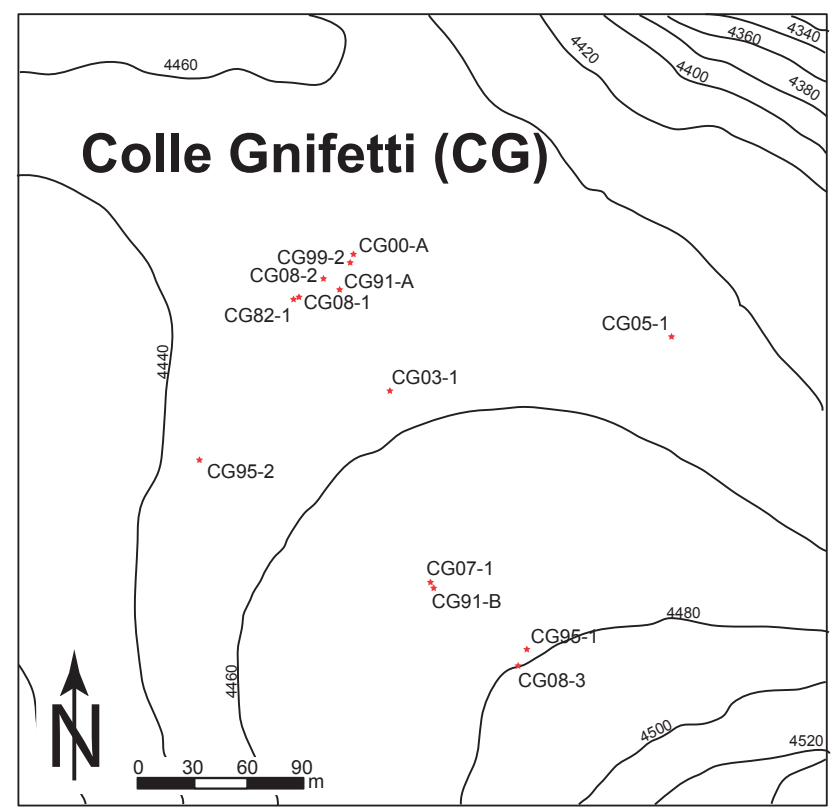

Fig. 2. Location of the borehole sites on Colle Gnifetti.

to $\pm 0.2{ }^{\circ} \mathrm{C}$ according to the expected lower most accuracy given by the different manufacturers. The relative accuracy between the thermistors of an individual thermistor chain using the same datalogger is however much higher. The three thermistor chains were connected to a Campbell CR10X data logger and Campbell AM416 multiplexer to make full-bridge measurements on the thermistors. The full-bridge was manufactured by AlpuG AG in Davos, Switzerland. The logger was powered by a $12 \mathrm{~V} / 24 \mathrm{Ah}$ lead battery.

\subsection{Locations}

A map showing all currently existing measurements sites since the late 1970s is presented in Fig. 1. In 2008, nine borehole temperature measurements sites were performed at three main locations in the Monte Rosa area. The first site was on Colle Gnifetti at altitudes between 4400 and $4500 \mathrm{~m}$ a.s.l. with three new and two already existing boreholes (Fig. 2), the second site was close to the Seserjoch at altitudes between 4250 and $4340 \mathrm{~m}$ a.s.l., with three new boreholes (Fig. 3) and the third site was on Grenzgletscher at an altitude of around $4250 \mathrm{~m}$ a.s.l. with one new borehole (also displayed in Fig. 3). The new boreholes and some selected existing ones are described in more detail in Table 1.

\subsection{Site and borehole numbering system}

We tried to find a convenient way to describe the drill and borehole sites. Therefore, we introduced two different codes. The first code is a "reader friendly" code used in this paper, which allows the finding of the different drill and 


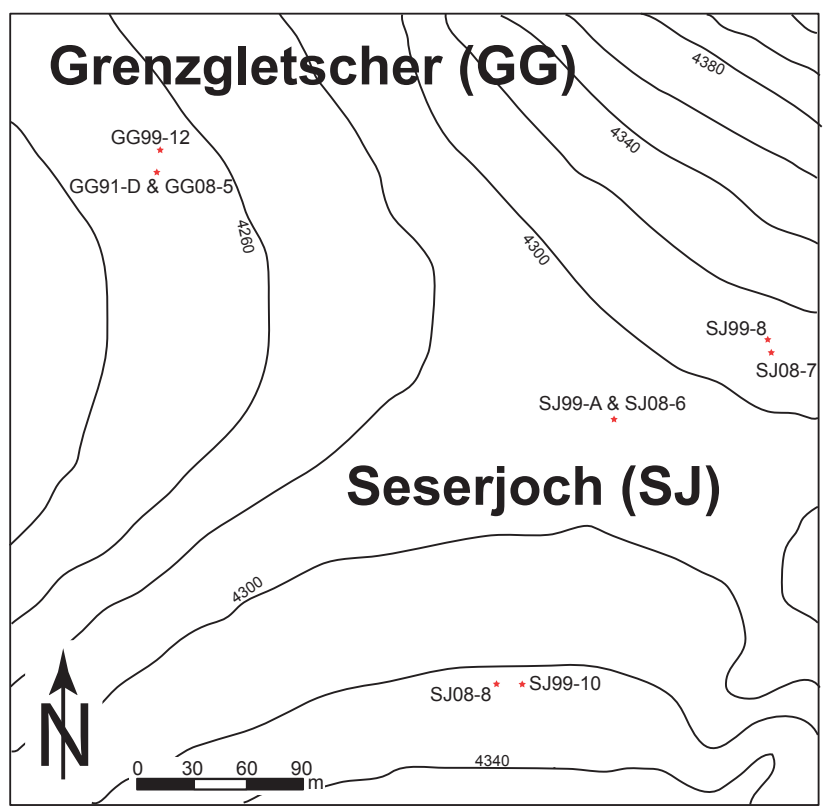

Fig. 3. Location of the borehole sites on Seserjoch and on Grenzgletscher.

measurement sites. The second code is a database code and is only given in Table 1 together with the first code. The code used in this paper reads as follows: CG95-1/97, the first two letters denote the location of the measurements, the second two letters describe the year of the drilling of the borehole, the next letter is a numbering of the drillings in the specific year, whereas the last two letters represent the year of the temperature measurement within the borehole. The database code looks as follows: B95-1_971018, the first letters describe the borehole with its year of drilling, the following number is based on the historical numbering system of the individual boreholes within a certain year, then the next number is the date of the temperature measurement in the borehole.

\subsection{Field measurements}

Depending on the objective of the measurements (core extraction or only temperature measurements), different drilling techniques were applied to establish the boreholes. Either mechanical drill equipment was used to extract ice cores, or steam drilling was applied if the objective was to take measurements of englacial temperatures only. A Heucke steam drill device with a special drill bit and $40 \mathrm{~m}$ of tubing was used to establish the boreholes. With this configuration, boreholes with a diameter of approx. 0.050 to $0.20 \mathrm{~m}$ were drilled. The average drilling time for a $25 \mathrm{~m}$ deep borehole was around $130 \mathrm{~min}$, varying between 75 and $165 \mathrm{~min}$ (Darms, 2009). After the drilling, the thermistor chains were lowered into the boreholes and the logger was connected.
The boreholes were always covered with an insulating rubber foam to prevent snow drift and near surface air circulation from penetrating the borehole. Potential air circulation in the borehole itself could lead to an internal heat transport. Experiments have shown that the impact of such a circulation is smaller than the accuracy of the thermistors (Schwerzmann, 2006; Zotikov, 1986). The measurements were done afterwards within 12 to $24 \mathrm{~h}$ using a sampling rate of 1 to $5 \mathrm{~min}$. If the measurements were taken directly after the drilling, the latent heat effects produced had to be taken into account (Oeschger et al., 1977; Laternser, 1992; Suter, 2002). Thermal adjustment of the thermistors to the surrounding temperature conditions required several days. Therefore, continuous logger readings had to be carried out in order to allow a later extrapolation to calculate the final undisturbed temperatures (Humphrey, 1991).

\subsection{Extrapolation procedure}

Steam drilling into cold firn or ice disturbs the temperature distribution in the close surroundings of the borehole. Therefore, a certain waiting period has to be allowed for until the temperatures have adjusted to the natural undisturbed conditions. In general it takes a few days for the measurement accuracy $0.1{ }^{\circ} \mathrm{C}$ to be reached (Laternser, 1992). To speed up the measurement time, extrapolation of continuous logger measurements directly after the drilling was carried out in order to obtain the final undisturbed temperatures. This procedure was applied at all drilling sites except at site CG07-1 with a fixed thermistor chain installation, and at CG03-1 and CG05-1 that had been drilled by an electro-mechanical auger. Thermal adjustment at these sites was assumed to have been completed already. The drilling procedure into cold firn or ice can be considered as an immediate perturbation (energy input) along a linear line (the borehole) (Suter, 2002). The model concept of an instantaneous line source seems to be a good approach in the case of steam drilling. The drilling time is assumed to be infinitely small and the energy input at a certain depth occurs at once. In the case of steam drilling, it is the energy input by the drill bit, whereas additional energy input caused by the insulated drill hose in the course of the drilling is rather small. In a homogenous infinitely expanded medium, the temperature field around a line source can be written as (Carslaw and Jaeger, 1959):

$\Delta T(r, t)=\frac{Q}{4 \pi K t} \cdot e^{\left(\frac{-\rho_{\mathrm{f}} \mathrm{c}_{\mathrm{i}} r^{2}}{4 K t}\right)}$

where $\Delta T(r, t)$ is the temperature difference between disturbed and undisturbed temperature, $r$ is the distance from line source, $t$ is the time since energy input, $Q$ is the energy input per unit length, $K$ is the thermal conductivity of firn, $\rho_{\mathrm{f}}=$ firn density and $c_{\mathrm{i}}=$ specific heat capacity of ice. As only the temperature along a central line of the borehole is of interest, $r$ equals 0 and if $\Delta T(r, t)$ is written as $T(t)-T_{\mathrm{f}}$, 
Table 1. Information about all boreholes mentioned in this study with measurement number, date and max. measurement depth, location and altitude of the boreholes, thermistors used and borehole drilling method.

\begin{tabular}{|c|c|c|c|c|c|c|c|c|}
\hline $\begin{array}{l}\text { borehole no } \\
\text { paper }\end{array}$ & $\begin{array}{l}\text { borehole no } \\
\text { database }\end{array}$ & date & $\begin{array}{l}\text { total depth } \\
\quad(\mathrm{m})\end{array}$ & $\begin{array}{c}\mathrm{x} \\
(\mathrm{m})\end{array}$ & $\begin{array}{c}\mathrm{y} \\
(\mathrm{m})\end{array}$ & $\begin{array}{l}\text { altitude } \\
\text { (m a.s.l.) }\end{array}$ & $\begin{array}{l}\text { thermistor } \\
\text { type }\end{array}$ & $\begin{array}{l}\text { drill } \\
\text { type }\end{array}$ \\
\hline CG76-1/77 & B76-1_7708 & 21 August 1977 & 50 & 633846 & 86617 & & & mechanical \\
\hline CG77-1/77 & B77-1_7700 & 21 August 1977 & 50 & 633846 & 86617 & & & mechanical \\
\hline CG82-1/82 & B82-1_8200 & 1982 & 120 & 633798 & 86576 & 4450 & & mechanical \\
\hline CG91-A/91 & B91-A_910809 & 9 August 1991 & 29 & 633820 & 86580 & 4452 & Fenwal 197-104QAG-A01 & steam \\
\hline CG91-B/91 & B91-B_911026 & 26 October 1991 & 28 & 633870 & 86420 & 4470 & Fenwal 197-104QAG-A01 & steam \\
\hline GG91-D/91 & B91-D_911026 & 26 October 1991 & 30 & 633500 & 85900 & 4250 & Fenwal 197-104QAG-A01 & steam \\
\hline CG95-1/97 & B95-1_971018 & 18 October 1997 & 60 & 633922 & 86383 & 4475 & Fenwal 197-103LAG-A01 & mechanical \\
\hline CG95-2/97 & B95-2_971018 & 18 October 1997 & 100 & 633746 & 86484 & 4448 & Fenwal 197-103LAG-A01 & mechanical \\
\hline SJ98-A/99 & B98-A_990901 & 1 September 1999 & 30 & 633750 & 85765 & 4293 & YSI 44006 & steam \\
\hline CG99-2/99 & B99-2_9905 & May 1999 & 22 & 633826 & 86595 & 4454 & YSI 44006 & steam \\
\hline SJ99-8/99 & B99-8_9905 & May 1999 & 22 & 633834 & 85808 & 4306 & YSI 44006 & steam \\
\hline SJ99-10/99 & B99-10_9905 & May 1999 & 22 & 633700 & 85620 & 4330 & YSI 44006 & steam \\
\hline GG99-12/99 & B99-12_9905 & May 1999 & 22 & 633502 & 85911 & 4250 & YSI 44006 & steam \\
\hline $\mathrm{CG} 00-\mathrm{A} / 00$ & B00-A_0008 & August 2000 & 25 & 633828 & 86599 & 4454 & YSI 44006 & steam \\
\hline CG03-1/03 & B03-1_030917 & 17 September 2003 & 80 & 633847 & 86524 & 4454 & Fenwal 197-103LAG-A01 & mechanical \\
\hline CG03-1/04 & B03-1_040515 & 15 May 2004 & 75 & 633847 & 86524 & 4454 & YSI 44031 & mechanical \\
\hline CG05-1/07 & B05-1_071104 & 4 November 2007 & 62 & 634002 & 86554 & 4452 & YSI 44031 & mechanical \\
\hline CG05-1/08 & B05-1_080824 & 4 November 2007 & 62 & 634002 & 86554 & 4452 & YSI 44031 & mechanical \\
\hline CG07-1/07 & B07-1_071104 & 4 November 2007 & 35 & 633872 & 86418 & 4470 & YSI 44031 & steam \\
\hline CG07-1/08 & B07-1_080824 & 4 November 2007 & 35 & 633872 & 86418 & 4470 & YSI 44031 & steam \\
\hline CG08-1/08 & B08-1_080824 & 24 August 2008 & 26 & 633795 & 86574 & 4450 & YSI 44031 & steam \\
\hline CG08-2/08 & B08-2_080824 & 24 August 2008 & 28 & 633811 & 86586 & 4452 & YSI 44031 & steam \\
\hline CG08-3/08 & B08-3_080824 & 24 August 2008 & 24 & 633918 & 86374 & 4483 & YSI 44031 & steam \\
\hline GG08-5/08 & B08-5_080825 & 25 August 2008 & 25 & 633500 & 85900 & 4250 & YSI 44031 & steam \\
\hline SJ08-6/08 & B08-6_080826 & 26 August 2008 & 24 & 633750 & 85765 & 4293 & YSI 44031 & steam \\
\hline SJ08-7/08 & B08-7_080826 & 26 August 2008 & 20 & 633836 & 85802 & 4306 & YSI 44031 & steam \\
\hline SJ08-8/08 & B08-8_080826 & 26 August 2008 & 31 & 633686 & 86620 & 4335 & YSI 44031 & steam \\
\hline
\end{tabular}

The first two letters of borehole no. used in this paper indicate: CG: Colle Gnifetti, GG: Grenzgletscher, SJ: Seserjoch.

the temperature at time $t$ after drilling is (Lachenbruch and Brewer, 1959)

$T(t)=\frac{Q}{4 \pi K} \cdot \frac{1}{t}+T_{\mathrm{f}}$

where $T_{\mathrm{f}}=$ undisturbed temperature or final temperature. Thus, $T(t)$ is proportional to $\frac{1}{t}$ and the final temperature $T_{\mathrm{f}}$ is the shift on the temperature axis and can be found at $\frac{1}{t}=0$ for $t \rightarrow \infty$. In theory, each depth would have a specific $t$ defining the time which had elapsed since the drill bit reached the corresponding depth. As the drilling time was rather short as compared to the sampling duration and as the measurement was only made several hours after drilling in most cases, the same $t$ was taken for the whole depth range and defined as the time which had elapsed since the end of the drilling and the measurement (Suter, 2002). This method was applied to all new boreholes except to the borehole CG07-1, where repeated temperature measurements in the same borehole were computed without using this method, because it was assumed that the thermal adjustment to undisturbed conditions had been completed.

\section{Results}

Methods and results of temperature measurements performed before 2003 are described in a number of already published studies (Lüthi and Funk, 2001; Suter, 2002; Suter and Hoelzle, 2002; Haeberli and Funk, 1985; Suter et al., 2001). Presented in this section are englacial temperatures measured in the boreholes drilled after 2003 mainly in 2007 and 2008, and their comparison to the measurements from the earlier studies (Tables 2 and 3). In addition, we show results of all deep temperature profiles collected within the last 30 years on Colle Gnifetti. Then, we relate the observed englacial temperature anomalies to the air temperature anomalies from the same time period (1980 to 2008) and compare the englacial temperature time series to already published results of the past (Lüthi, 2000; Suter, 2002). In a first step, we compared the temperature measurements at a depth of around $20 \mathrm{~m}$, corresponding to the zero annual amplitude (ZAA), where seasonal fluctuations are less than $\pm 0.1^{\circ} \mathrm{C}$ (e.g. see Fig. 5, Tables 2 and 3). On Colle Gnifetti, we have a total of 13 drilling sites with around 20 individual temperature measurements. Figure 4 contains the measured 


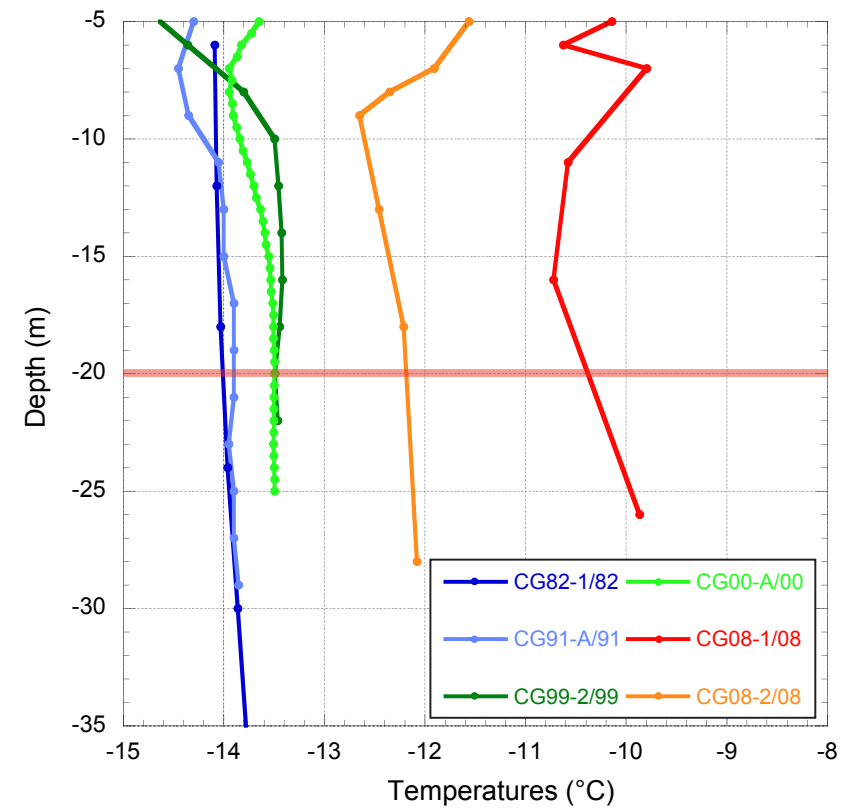

Fig. 4. Temperatures measured at CG82-1/82 (Haeberli and Funk 1991), CG91-A/91 (Laternser 1992), CG99-2/99 and CG00-A/00 (Suter 2002) compared with the new measurements at CG08-1/08 and CG08-2/08 at Colle Gnifetti shown in Fig. 2.

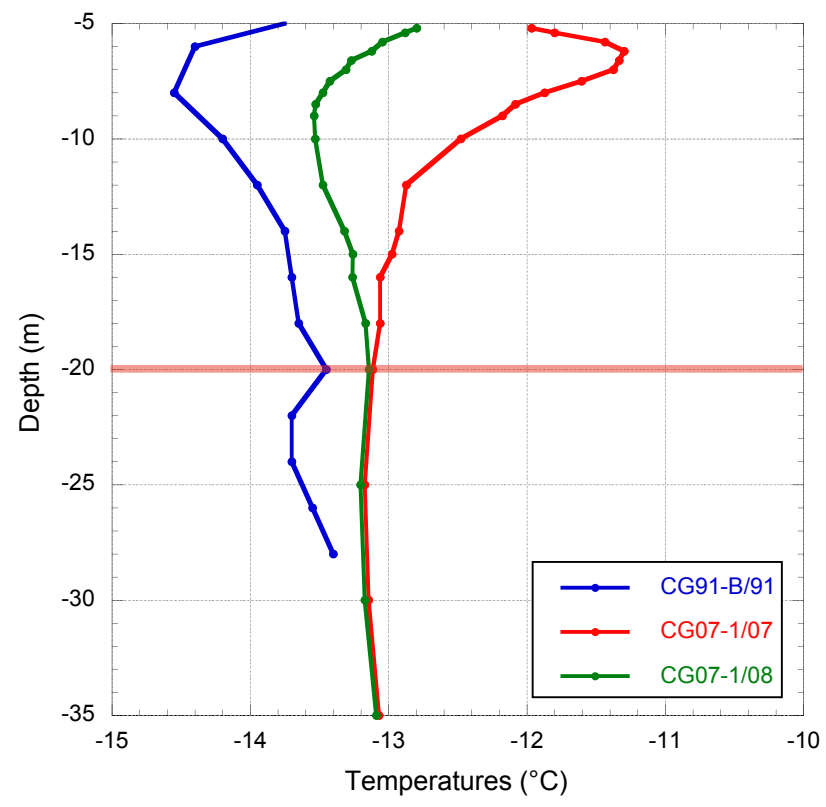

Fig. 5. Temperatures measured in CG91-B/91 (Laternser 1992), compared with the new measurements in CG07-1/07 and CG071/08 at Colle Gnifetti.
Table 2. Information about temperatures measured at $20 \mathrm{~m}$ depth for all measurement sites with measurement number, date and depth.

\begin{tabular}{llcc}
\hline drilling site & date & $\begin{array}{c}\text { temperature } \\
\left({ }^{\circ} \mathrm{C}\right)\end{array}$ & $\begin{array}{c}\text { depth } \\
(\mathrm{m})\end{array}$ \\
\hline CG82-1/82 & 1982 & -14.1 & 20 \\
CG91-A/91 & 2 August 1991 & -13.9 & 20 \\
CG91-B/91 & 26 October 1991 & -13.5 & 20 \\
GG91-D/91 & 26 October 1991 & -9.3 & 20 \\
CG95-1/96 & 19 July 1996 & -13.33 & 20 \\
CG95-2/96 & 19 July 1996 & -13.46 & 26 \\
SJ98-A/99 & 1 September 1999 & -9.55 & 20 \\
CG99-2/99 & May 1999 & -13.49 & 20 \\
SJ99-8/99 & May 1999 & -6.79 & 16 \\
SJ99-10/99 & May 1999 & -13.00 & 20 \\
GG99-12/99 & May 1999 & -3.81 & 20 \\
CG00-A/00 & August 1999 & -13.49 & 20 \\
CG03-1/03 & 17 September 2003 & -13.54 & 20 \\
CG03-1/04 & 15 May 2004 & -13.50 & 20 \\
CG05-1/07 & 3 November 2007 & -12.99 & 20 \\
CG05-1/08 & 25 August 2008 & -12.87 & 20 \\
CG07-1/07 & 3 November 2007 & -13.11 & 20 \\
CG07-1/08 & 27 August 2008 & -13.14 & 20 \\
CG08-1/08 & 24 August 2008 & -10.38 & 20 \\
CG08-2/08 & 24 August 2008 & -12.18 & 20 \\
CG08-3/08 & 24 August 2008 & -12.37 & 20 \\
GG08-5/08 & 25 August 2008 & -2.52 & 20 \\
SJ08-6/08 & 26 August 2008 & -7.15 & 20 \\
SJ08-7/08 & 26 August 2008 & -6.40 & 19 \\
SJ08-8/08 & 26 August 2008 & -11.52 & 20 \\
\hline
\end{tabular}

temperatures in the boreholes CG08-1/08 and CG08-2/08 compared to the older measurements of CG82-1/82, CG91A/91, CG99-2/99 and CG00-A/00. All these measurements are situated in the relatively flat saddle point on Colle Gnifetti within a short radius of around $50 \mathrm{~m}$ (Fig. 2). The comparison shows that the temperatures at a depth of $20 \mathrm{~m}$ indicate no change between 1982 and 1991 and have a value of around $-14.0^{\circ} \mathrm{C}$. Between 1991 and 1999/2000 a temperature increase of $0.5^{\circ} \mathrm{C}$ was measured. Since 2000 the temperatures have increased again by at least $1.3^{\circ} \mathrm{C}$. The measurement in CG08-1/08 further downslope already shows a $1.8^{\circ} \mathrm{C}$ higher temperature at $20 \mathrm{~m}$ depth.

The next site is situated on the northwestern slope of Colle Gnifetti beneath Signalkuppe. At this location a borehole was drilled in 1991 (CG91-B/91) and described by Laternser (1992) and Suter et al. (2001). In 2007 (CG07-1/07), a permanent thermistor chain was installed and remeasured in 2008 (CG07-1/08). At a depth of $20 \mathrm{~m}$, a slight increase in temperature of around 0.4 to $0.5^{\circ} \mathrm{C}$ was observed between 1991 and $2007 / 8\left(0.031^{\circ} \mathrm{C}\right.$ per year, Fig. 5). On the same northwestern slope but around 10 meter higher up are the two boreholes CG95-1/97 measured already by Lüthi (2000) and CG08-3/08 (Fig. 6). The increase of temperature at this site is 
Table 3. Information about temperatures changes measured at $20 \mathrm{~m}$ depth for some selected measurement sites.

\begin{tabular}{llc}
\hline boreholes & measurement period & $\begin{array}{c}\text { temperature change } \\
\text { in 20 m depth }\left({ }^{\circ} \mathrm{C}\right)\end{array}$ \\
\hline CG82-1/82 to CG08-1/08 & 1982 to 24 August 2008 & 3.72 \\
CG91-A/91 to CG08-2/08 & 2 August 1991 to 24 August 2008 & 1.72 \\
CG95-1/96 to CG08-3/08 & 19 July 1996 to 24 August 2008 & 0.96 \\
GG91-D/91 to GG99-12/99 & 26 October 1991 to May 1999 & 5.49 \\
CG00-A/00 to CG08-2/08 & August 1999 to 24 August 2008 & 1.31 \\
GG99-12/99 to GG08-5/08 & May 1999 to 25 August 2008 & 1.29 \\
SJ98-A/99 to SJ08-6/08 & 1 September 1999 to 26 August 2008 & 2.40 \\
SJ99-8/99 to SJ08-7/08 & May 1999 to 26 August 2008 & 0.39 \\
SJ99-10/99 to SJ08-8/08 & May 1999 to 26 August 2008 & 1.48 \\
CG91-B/91 to CG07-1/07 & 26 October 1991 to 3 November 2007 & 0.36 \\
\hline
\end{tabular}

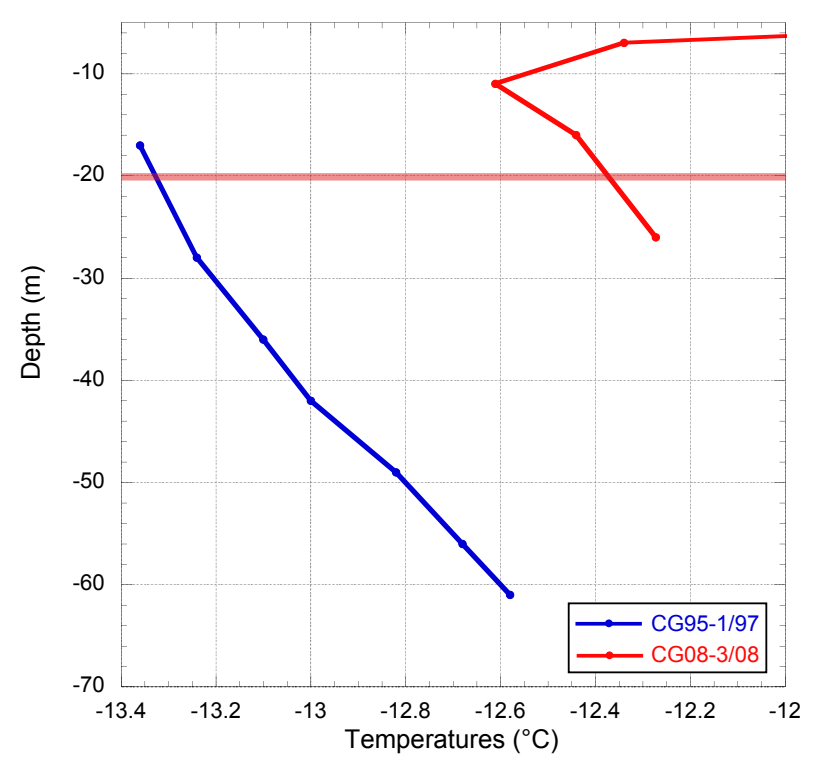

Fig. 6. Temperatures measured in CG95-1/97 (Lüthi 2000), compared with the new measurements at CG08-3/08 at Colle Gnifetti.

around $1.0{ }^{\circ} \mathrm{C}$ (or $0.087^{\circ} \mathrm{C}$ per year, Table 3 ). All these three sites on Colle Gnifetti show a temperature increase, which is far above the accuracy of the thermistors and is considerable on the saddle point and at least on the uppermost site on the northwestern slope of Signalkuppe.

Close to Seserjoch, several boreholes were drilled in 1999 and they are described by Suter (2002). The borehole SJ9910/99 and SJ08-8/08 were drilled at the northern slope of Parrotspitze (see Fig. 3). The observed increase at this location is $1.5^{\circ} \mathrm{C}$ (Fig. 7, Table 3). On the Seserjoch saddle a borehole was drilled in 1998 (SJ98-A/99) and measured in 1999. In 2008 at the same place a new borehole was drilled and measured (SJ08-6/08). The observed increase in temperature was $2.4^{\circ} \mathrm{C}$ (Fig. 8). Another borehole pair located on

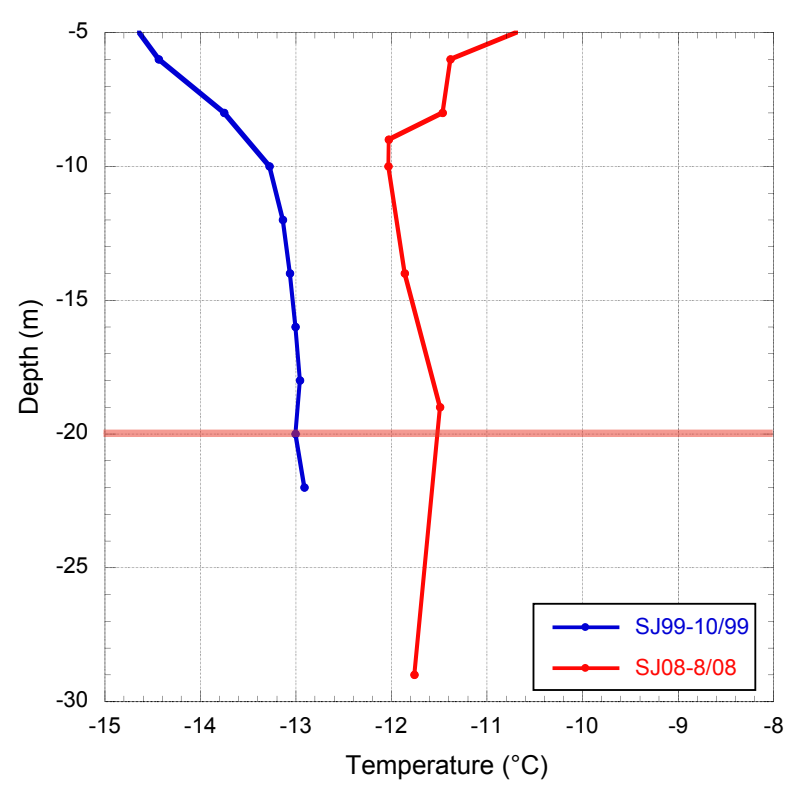

Fig. 7. Temperatures measured in SJ99-10/99 (Suter 2002) at Seserjoch, compared with the new measurements at SJ08-8/08.

the southwestern slope of Signalkuppe are the measurements SJ99-8/99 and SJ08-7/08. These measurements show an increase of around $0.4{ }^{\circ} \mathrm{C}$ (Table 3 ). On Seserjoch all three sites show an increase in temperature, which is in a similar range like the observed ones on Colle Gnifetti but the absolute temperature are in general several degrees warmer.

On Grenzgletscher, two boreholes were drilled in 1991 and 1999 by Laternser (1992) and Suter (2002) at the nearby location of Seserjoch on a western slope (GG91-D/91, GG9912/99 and GG08-5/08, Figs. 3 and 9). A very strong increase in temperature was observed between 1991 and 1999. The observed temperature increase was around $5.5^{\circ} \mathrm{C}$ and in the second observation period between 1999 and $20081.3^{\circ} \mathrm{C}$ (Table 3). Again like at the other two places on Colle Gnifetti 


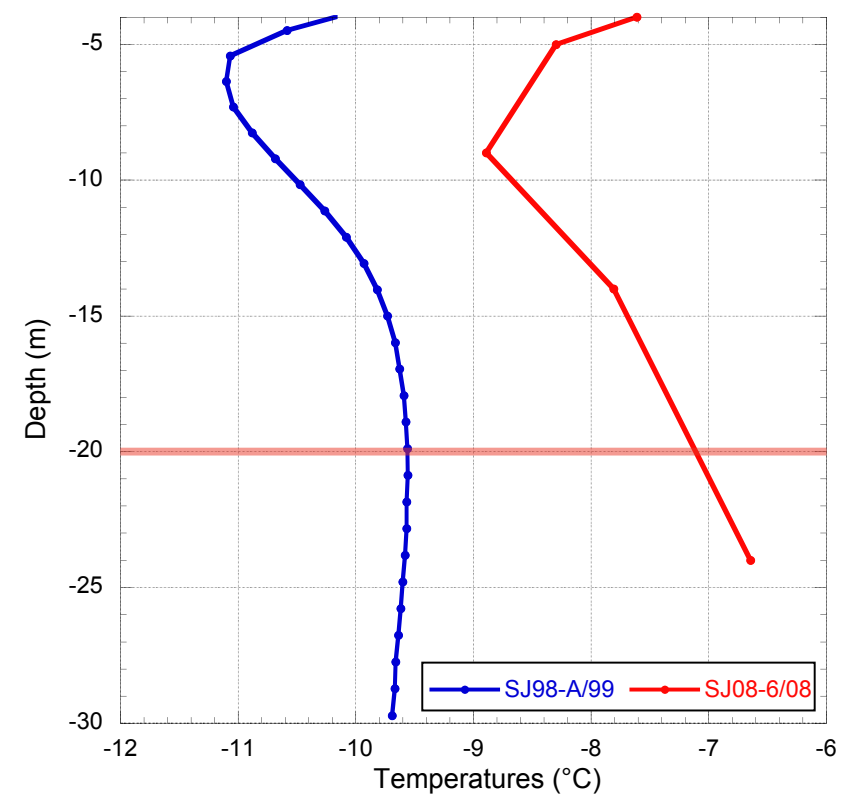

Fig. 8. Temperatures measured in SJ98-A/99 (Suter 2002) at Seserjoch, compared with the new measurements at SJ08-6/08.

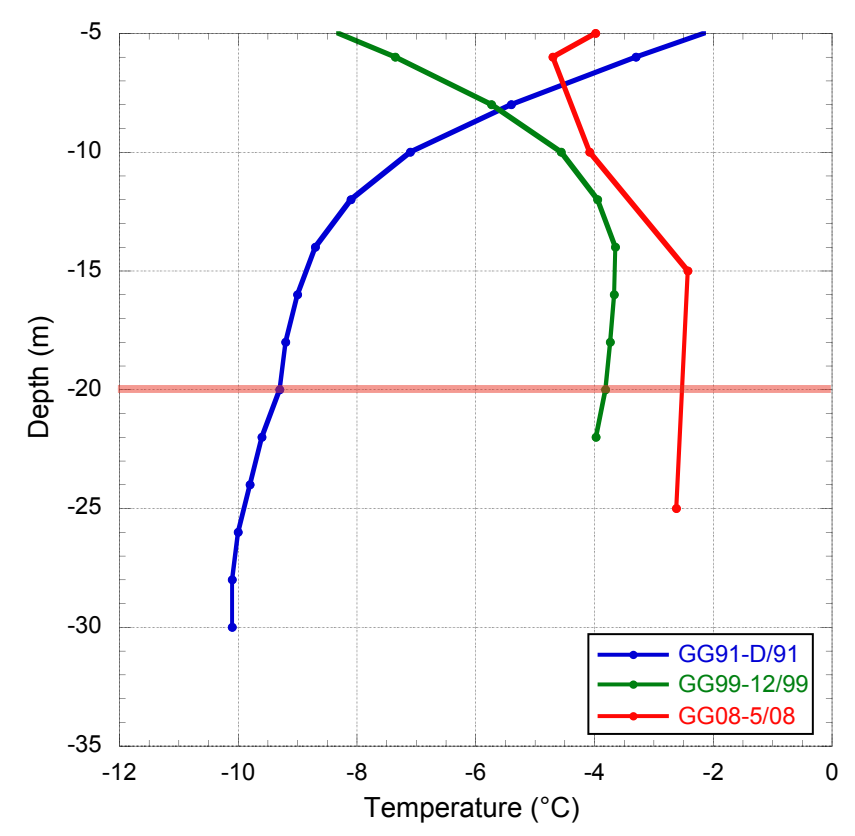

Fig. 9. Temperatures measured in GG91-D/91 (Laternser 1992) and GG99-12/99 (Suter 2002) on Grenzgletscher, compared with the new measurements at GG08-5/08.

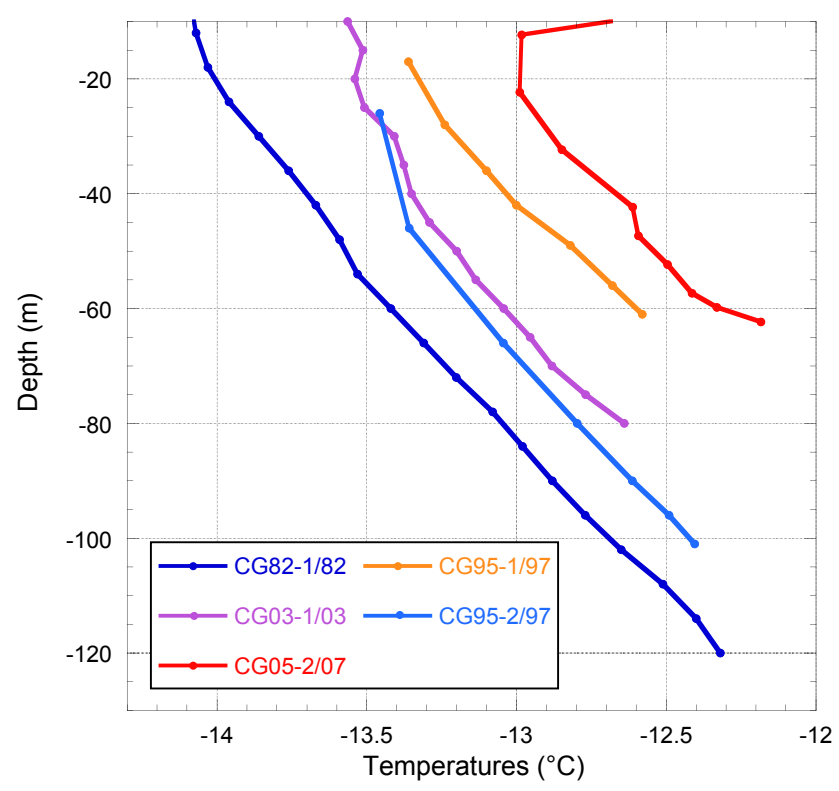

Fig. 10. Temperatures profiles measured in the deep boreholes CG82-1/82 (Haeberli and Funk, 1991), CG95-1/97 and CG95-2/97 (Lüthi, 2000), CG03-1/03 (Schwerzmann, 2006) and CG05-1/07 (this study).

and Seserjoch, the increase of the englacial temperature is very pronounced.

In Fig. 10, we present temperature measurements from five deep boreholes, which were drilled during the last thirty years. The boreholes are described in detail in Table 1. Characteristic at all five boreholes is that the observed profiles are slightly bend to warmer temperatures and show low temperature gradients in the corresponding uppermost profile parts starting in a depth of around $50 \mathrm{~m}$ to $60 \mathrm{~m}$ (Figs. 10 and 11).

The effects shown in the previous figures show a clear warming at all sites on Colle Gnifetti, Seserjoch and Grenzgletscher. We tried now to relate the observed increase in englacial temperatures to the direct observed atmospheric temperatures. Therefore, we used two air temperature series, one from the Jungfraujoch site observed by MeteoSwiss and the second one by the Histalp (Historical Instrumental Climatological Surface Time Series of the Greater Alpine Region) (Auer et al., 2007). We plotted temperature anomalies for all three time series to allow a direct comparison instead of using the absolute values, which would necessitate an adjustment of the air temperature with an unknown lapse-rate. The temperature anomalies presented in Fig. 12 show first that the two used temperature series are quite similar and second that there is a strong warming of the air temperatures at the end of the 1980s, whereas the englacial temperature increase mainly occurs since 2000 . 


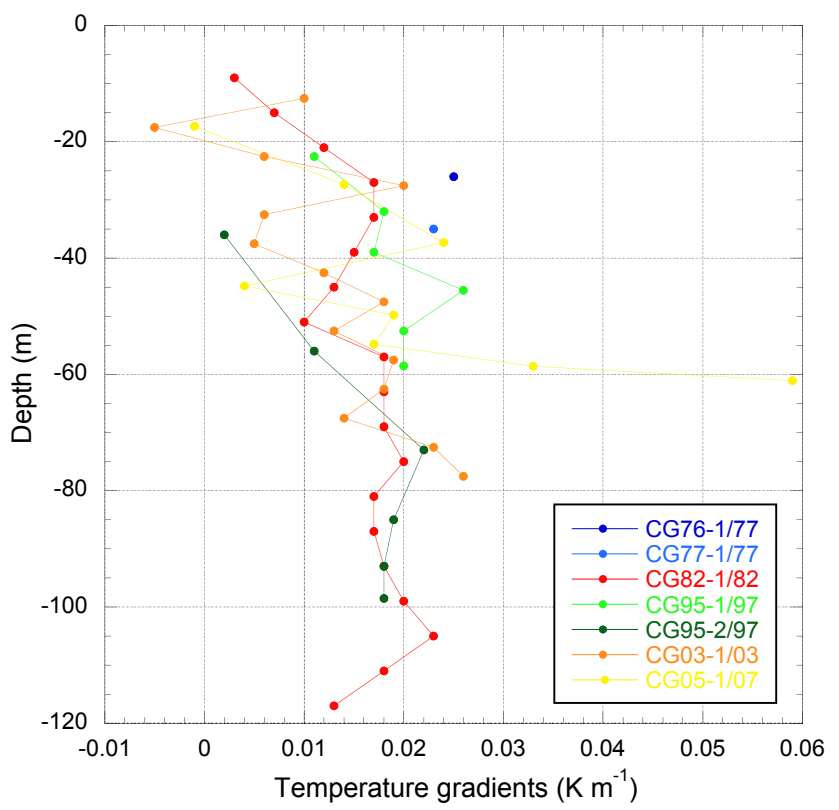

Fig. 11. Calculated temperature gradients for the temperature profiles shown in Fig. 10 with CG77-1/77 and CG77-2/77 (Oeschger et al., 1977), CG81-1/82 (Haeberli and Funk 1991), CG95-1/97 and CG95-2/97 (Lüthi, 2000), CG03-1/03 (Schwerzmann, 2006) and CG05-1/07 (this study).

\section{Discussion}

All the investigated sites in the whole Monte Rosa area show a clear trend towards higher englacial temperatures since 1991 beyond the accuracy of the measurements. The magnitude of the increase, however, varies significantly between the different sites as an expression of the different amount of available melt energy within the surface energy balance, which determines the amount of infiltrating and refreezing surface meltwater within the firn (Suter et al., 2004). This important process is supplemented by a general decrease of the thermal conductivity with warmer englacial temperatures (Paterson, 1994). In general, there is a clear trend toward accelerated warming at the saddle point of Colle Gnifetti which goes beyond the air temperature increase and gives evidence of an increasing meltwater percolation.

The measured $20 \mathrm{~m}$ englacial temperature at the different observation sites vary significantly in space and time. At Colle Gnifetti the observed temperatures are in a range of $-14.1^{\circ} \mathrm{C}$ to $-10.38^{\circ} \mathrm{C}$, at Seserjoch between $-13.0^{\circ} \mathrm{C}$ and $-6.4^{\circ} \mathrm{C}$ and at Grenzgletscher between $-9.3^{\circ} \mathrm{C}$ and $-2.52^{\circ} \mathrm{C}$ (Table 2).

The measured temperatures at the sites close to the saddle point of Colle Gnifetti (see Figs. 2 and 4) show a very strong variability of the warming. The observed warming between the boreholes CG82-1/82 to CG08-1/08 is $3.72{ }^{\circ} \mathrm{C}$,

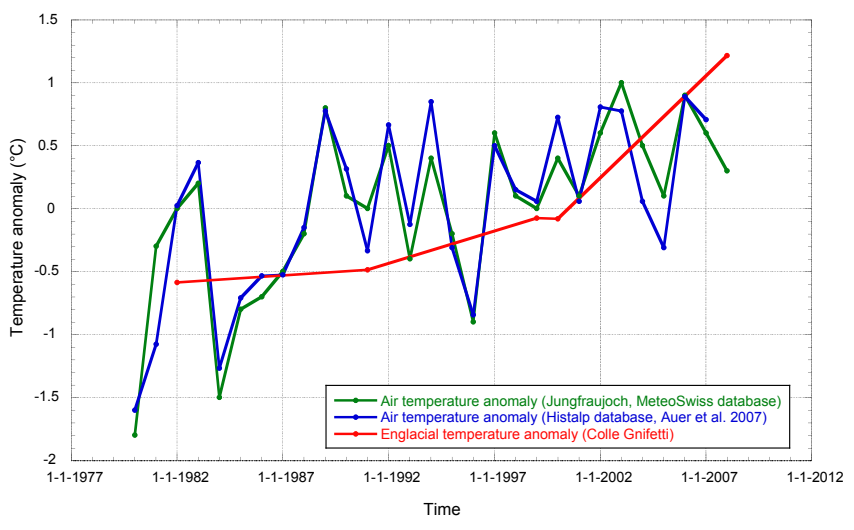

Fig. 12. Measured air temperature anomaly with data from Jungfraujoch (MeteoSwiss, anomaly reference period 1980 to 2008) and from the Histalp database (Auer et al., 2007, anomaly reference period 1980 to 2007) in comparision with the englacial temperature anomaly measured in $20 \mathrm{~m}$ depth at Colle Gnifetti (anomaly reference period for the anomaly 1982 to 2008 , the used temperature measurements were CG82-1/82, CG91-A/91, CG99-2/99, CG001/00, CG08-2/08).

whereas the warming at the nearby site CG91-A/91 to CG08$2 / 08$ is $1.72^{\circ} \mathrm{C}$. This clearly shows the very high spatial variability of near surface temperature distribution, which is strongly affected by topography (slope and aspect, representing different incoming shortwave radiation amounts) and different accumulation rates. Especially, the accumulation rates show a strong variation on Colle Gnifetti. Highest accumulation rates are found on the south slope of Zumsteinspitze and close to the saddle point, whereas the lowest accumulation rates are found on the northeastern side of Signalkuppe (Alean et al., 1983; Lüthi, 2000; Suter, 2002). Therefore, it can be assumed that high wind speeds and the topography affect mainly the deposition of the snow at this site but a temperature or probably more a shortwave radiation effect is likely to exist preventing the erosion of snow at the warmer south slopes by the generation of refreezing melt layers. Therefore, shortwave radiation on a smaller area and probably air temperature on a larger area are positively correlated with the accumulation (Haeberli and Alean, 1985) and influence considerably the observed thermal regime within the firn. An other effect, one could assume is that the $20 \mathrm{~m}$ temperatures are influenced by horizontal advection in the upper most $20 \mathrm{~m}$ of the cold firn saddle of Colle Gnifetti. According to several flow studies in the past by Wagner (1996); Lüthi (2000); Schwerzmann (2006) the horizontal and vertical flow velocities at the Colle Gnifetti saddle point are very small and can be considered to be not significant in this context.

In addition to the $20 \mathrm{~m}$ englacial temperatures, the five boreholes on Colle Gnifetti with measured temperature down to bedrock show all slight bending to higher temperatures in 
their uppermost profile part and are, thus, not in a steadystate situation. This indicates a still ongoing warming of the firn, which can be related to the observed atmospheric warming in the last 20 years and is additionally supporting the observed warming trend in the $20 \mathrm{~m}$ temperatures. In addition, we observe at these temperature profiles that the temperatures at the firn - bedrock transition are in a range of $-13^{\circ} \mathrm{C}$ to $-12^{\circ} \mathrm{C}$ and that the temperatures measured in the boreholes in the western part of the Colle Gnifetti firn saddle are in general colder than on the more eastern part. Probably, we are able here to detect the effects of topography influencing the temperatures, especially at the boreholes CG95-1/97 in the upper part of the northwestern slope of Signalkuppe as well as at the borehole CG05-2/07 at the most eastern part of the saddle close to the steep Monte Rosa east face. This effect is confirmed by the plotted temperature gradients in Fig. 11, which show slightly higher temperature gradients in these two boreholes in the lower parts of the boreholes than in the other three boreholes. Such effects are well known and confirmed by many modelling studies (Lüthi and Funk, 2001; Wegmann et al., 1998; Noetzli et al., 2007; Noetzli and Gruber, 2009).

The other two sites have a slightly different behaviour, mainly because they are situated at lower elevations and have other topographical conditions. The Grenzgletscher site show a strong increase of $5.5^{\circ} \mathrm{C}$ already in the 1991 to 1999 period but a decelerated warming until 2008 (Fig. 9, boreholes GG91-D/91 and GG99-12/99). This can be explained by the change of the firn facies zone, where the effect of percolating melt water causes the strongest impact when changing from the dry cold recrystallisation-infiltration zone to the cold infiltration zone. The observed decelerated warming in the second period is based on the effect that as closer the temperatures come to zero degree, the slower the warming. Small amounts of liquid water occur even at temperatures close to $-10{ }^{\circ} \mathrm{C}$ and the liquid water content is continuously rising if temperatures are increasing. This means that one part of the available energy is still used to warm the firn/ice and the existing liquid water while another part of the energy is already used to melt the firn/ice (Harrison, 1972). Therefore, as more energy is used for the phase change from firn/ice to water the warming of the firn/ice starts to slow down. The same effect is probably starting to occur at the boreholes at the Seserjoch between 1999/2000 and 2008 but at this site only one measurement period is available.

The warming of air temperatures represented by the plotted anomalies for the high Alpine station of Jungfraujoch and for the Histalp data show a measured warming for the whole observation period from 1980 to 2008 of around $0.05^{\circ} \mathrm{C}$ per year and is therefore lower than the observed warming in the boreholes on the Colle Gnifetti saddle site at $4452 \mathrm{~m}$ a.s.l. (Figs. 4 and 12). The englacial temperatures revealed no evidence of warming between 1982 and 1991, the 1991 to 2000 period showed an increase of $0.05^{\circ} \mathrm{C}$ per year at a depth of $20 \mathrm{~m}$. From 2000 to 2008 a further increase of $1.3^{\circ} \mathrm{C}$ or

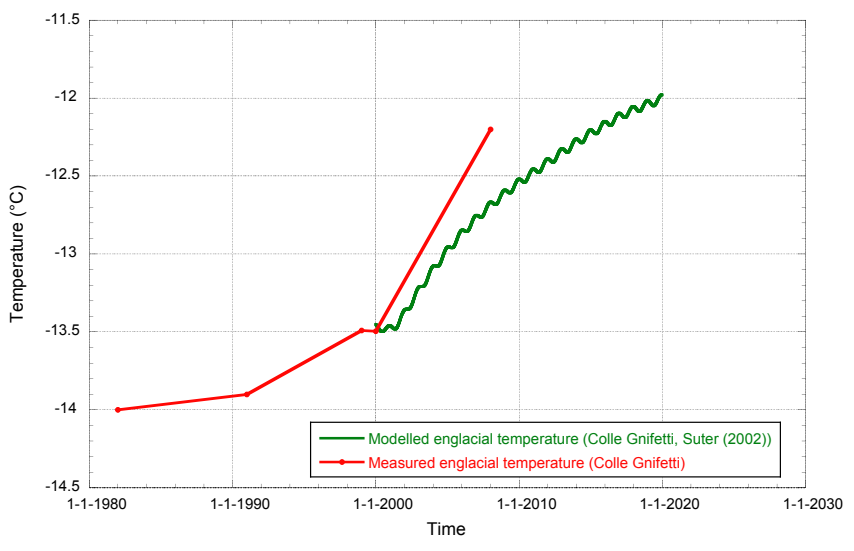

Fig. 13. Modelled englacial temperatures in $18 \mathrm{~m}$ depth for the years 2000 to 2020 assuming an increase of air temperature of $0.45^{\circ} \mathrm{C}$ until 2020 based on a study by Suter (2002) compared with the measured englacial temperature in $20 \mathrm{~m}$ depth since 1982 (the used temperature measurements were CG82-1/82, CG91-A/91, CG99-2/99, CG00-1/00, CG08-2/08).

$\left(0.16^{\circ} \mathrm{C}\right.$ per year) was observed. The strong air temperature increase starting in the 1980s is well reflected in Fig. 12 and one should be aware that the $20 \mathrm{~m}$ englacial temperatures are a smoothed and delayed signal having a time lag of about 2 to 4 years depending on the assumed accumulation rates. In addition, the englacial temperature series are not as continuous as the air temperature series and we do not know if for example the influence of the strong heat wave in 2003 over Europe had a considerably influence on the warming of these firn areas or not. However, Suter (2002) could show in his study that the total amount of melt energy released into the firn is the most important factor and therefore, the assumption that the long period of very high temperatures observed in 2003 led to a significant warming of the firn is plausible.

In this context, we relate our findings to two studies by Lüthi (2000) and Suter (2002) who already modelled the englacial temperatures on Colle Gnifetti at the beginning of the new century assuming different scenarios. Details about these two model studies can be found in Suter (2002) and Lüthi (2000). In Fig. 13 the observed englacial temperature series are directly compared with the modelled data from the study performed by Suter (2002), who modelled the englacial temperatures at the same site, where the observed long-term englacial temperature series exist (Figs. 2 and 4). Suter (2002) assumed an air temperature increase of $0.45^{\circ} \mathrm{C}$ from 2000 until 2020 . The measured englacial temperature in 2008 is $-12.2^{\circ} \mathrm{C}$ corresponding to a modelled englacial temperature in the year 2015. This result reveals that the observed warming is considerable faster than the previous assumed scenario by Suter (2002). Also Lüthi (2000) modelled the englacial temperatures at the site CG95-1/97 assuming a linear increase of one degree within the next fifty years after 
a past IPCC-scenario. The modelled temperature increase by Lüthi (2000) from 1997 to 2050 is $0.95^{\circ} \mathrm{C}$. The observed temperature increase from 1997 to 2008 is $0.96^{\circ} \mathrm{C}$ indicating again a much stronger warming than originally inferred by the model.

Based on these findings, it must be assumed that an important firn area beneath the Colle Gnifetti had already changed after 1991 from a recrystallisation-infiltration to a cold infiltration zone. However, probably most parts of the Colle Gnifetti itself are thus still situated in the recrystallisationinfiltration zone but ongoing warming could lead to a similar situation as on Grenzgletscher and at the Seserjoch, where a facies change was observed after a temperature of around $-9{ }^{\circ} \mathrm{C}$ was reached at the ZAA. The warming of the englacial temperatures on Colle Gnifetti is stronger at the saddle point than on north-exposed slopes. The opposite is observed on Seserjoch. This is due to the fact that Colle Gnifetti starts only now to be influenced by meltwater. On Seserjoch, meltwater influence began already in the early 1990s (Table 3).

Additionally, we would like to mention that such processes may also occur at many sites in high altitude mountain regions in the Arctic or Antarctic, where temperatures are in the same range as on Monte Rosa. However, one should be aware that the englacial warming in Arctic as well as in Antarctic regions is not directly comparable with the high mountain sites in the mid latitudes due to different diurnal and seasonal insolation cycles (Fritzsche et al., 2005). In general, this leads to higher firn temperatures although the mean annual air temperatures could be somewhat colder than the ones in the mid latitudes. However, the processes leading first to a change from the recrystallisation-infiltration to the cold infiltration facies zone are likely to prevent an increase in meltwater production for a longer time period and therefore mass loss at such sites. As soon as all these areas become temperate, meltwater will be released in large quantities into the water cycle and enhance the already rising sea level. We therefore recommend that temperature profiles be measured at all sites with cold firn areas where in-situ mass balance measurements are performed.

\section{Conclusions}

The high-altitude firn areas of the Monte Rosa have been influenced by a significant warming trend since the beginning of the 1990s. It must be assumed that larger firn areas below the Colle Gnifetti firn saddle have already undergone a firn facies change from a recrystallisation-infiltration to a cold infiltration zone. The englacial temperature change at the Colle Gnifetti firn saddle is very significant. Between 2000 and 2008 an accelerated warming trend was observed as compared to the time period from 1991 to 2000 . This warming is beyond the observed air temperature increase in high mountain areas of the Alps and gives evidence of the increasing influence of penetrating and refreezing meltwater since 2000. If the warming trend goes on as observed between 2000 and 2008, the increasing meltwater influence could lead to the destruction of this very important old ice archive within the next decades. The englacial warming currently being observed is also far beyond the modelled warming at Colle Gnifetti based on past IPCC scenarios (Lüthi, 2000; Suter, 2002). There is a need for further research in this area and modelling studies in connection with measurements could lead to better interpretations of the now observed changes and their causes (e.g., Lüthi and Funk, 2001; Suter, 2002; Vincent et al., 2007b; Gilbert et al., 2010). Therefore, the monitoring of the development of the englacial temperatures at this high altitude Alpine site is now included as part of the operational cryospheric measurements in the Swiss Alps by the Cryospheric Commission of the Swiss Academy of Sciences. All borehole data are freely available at the following website: www.cryosphere.ch.

Acknowledgements. We would like to thank all the students and scientific collaborators who helped over more than 30 years to collect this data. Special thanks go to Martin Funk, Laboratory of Hydraulics, Hydrology and Glaciology, ETH Zurich, Martin Laternser, Frances Lake Wilderness Lodge, Yukon, Canada, Ralph Böhlert, Wilfried Haeberli and Michael Zemp Department of Geography, University of Zurich, Aurel Schwerzmann, SwissRe, New York and Matthias Huss, Department of Geosciences, University of Fribourg who performed many of the earlier measurements, allowed the use of their data within this study and commented kindly an earlier draft of this paper. Sincere thanks to Susan Braun for improving the English. Special thanks are extended to the research groups of Dietmar Wagenbach, Environmental Physics, University of Heidelberg (boreholes CG82-1, CG95-1, CG95-2, CG05-1), who provided us with very valuable comments as a reviewer, Hans Oeschger ${ }^{\dagger}$, Climate and Environmental Physics, University of Bern (boreholes CG76-1, CG77-1), Heinz Gäggeler and Margit Schwikowski, Paul-Scherrer-Institute, Villigen (borehole CG03-1), Olaf Eisen, Alfred Wegener Institute, Bremerhaven, Wilfried Haeberli, Department of Geography, University of Zurich for the use of their boreholes and logistics and to the Cryospheric Commission of the Swiss Academy of Sciences for their financial support. Without their support this valuable temperature database would not exist at all.

Edited by: D. Hall

\section{References}

Alean, J., Haeberli, W., and Schädler, B.: Snow accumulation, firn temperature and solar radiation in the area of Colle Gnifetti core drilling site, Zeitschrift für Gletscherkunde und Glazialgeologie, 19, 131-147, 1983.

Auer, I., Böhm, R., Jurkovic, A., Lipa, W., Orlik, A., Potzmann, R., Schöner, W., Ungersböck, M., Matulla, C., Briffa, K., Jones, P. D., Efthymiadis, D., Brunetti, M., Nanni, T., Maugeri, M., Mercalli, L., Mestre, O., Moisselin, J. M., Begert, M., MüllerWestermeier, G., Kveton, V., Bochnicek, O., Stastny, P., Lapin, 
M., Szalai, S., Szentimrey, T., Cegnar, T., Dolinar, M., GajicCapka, M., Zaninovic, K., Majstorovic, Z., and Nieplova, E.: HISTALP Historical Instrumental Climatological Surface Time Series of the Greater Alpine Region, Int. J. Climatol., 27, 17-46, 2007.

Blatter, H. and Hutter, K.: Polythermal conditions in Arctic glaciers, J. Glaciol., 37, 261-269, 1991.

Benson, C. S.: Stratigraphic studies in the snow and firn of the Greenland Ice Sheet, Folia Geographica Danica, 9, 13-37, 1961.

Böhlert, R.: Glaziologische Untersuchungen auf dem Colle Gnifetti und auf dem Mont Blanc: ermittlung der Eisdickenverteilung und interner Schichten mittels Georadar, MSc thesis, University of Zürich, 2005.

Carslaw, H. S. and Jaeger, J. C.: Conduction of heat in solids, Clarendon Press, Oxford, 2 Edn., 1959.

Cuffey, K. M. and Paterson, W. S. B.: The Physics of Glaciers, 4 Edn., Butterworth-Heinemann, Oxford, 704 pp., 2010.

Darms, G. A.: Firntemperaturen auf dem Colle Gnifetti. Zusammenstellung und Analyse bestehender und neuer Temperaturprofile. MSc thesis, University of Zürich, 2009.

Fisher, J. E.: The cold ice tunnel on the Silbersattel, Monte Rosa, J. Glaciol., 2, 195-19, 1953.

Fisher, J. E.: The cold ice tunnel on the Silbersattel, Monte Rosa (progress 1953), J. Glaciol., 2, 341, 1954.

Fisher, J. E.: Internal temperatures of a cold glacier and conclusions therefrom, J. Glaciol., 2, 583-591, 1955.

Fisher, J. E.: Two tunnels in cold ice at $4000 \mathrm{~m}$ on the Breithorn, J. Glaciol., 4, 513-520, 1963.

Gilbert, A., Wagnon, P., Vincent, C., Ginot, P., and Funk, M.: Atmospheric warming at a high-elevation tropical site revealed by englacial temperatures at Illimani, Bolivia $(6340 \mathrm{~m}$ above sea level, $\left.16^{\circ} \mathrm{S}, 67^{\circ} \mathrm{W}\right)$, J. Geophys. Res., 115, doi:10.1029/2009JD012961, 2010.

Fritzsche, D., Schütt, R., Meyer, H., Miller, H., Wilhelms, F., Opel, T., and Savatyugin, L. M.: A 275 year ice-core record from Akademii Nauk ice cap, Severnaya Zemlya, Russian Arctic, Ann. Glaciol., 42, 361-366, 2005.

Haefeli, R. and Brentani, F.: Observations in a cold ice cap, J. Glaciol., 2, 571-581, 1955.

Haeberli, W.: Eistemperaturen in den Alpen, Zeitschrift für Gletscherkunde und Glazialgeologie, 11, 203-220, 1976.

Haeberli, W. and Alean, J.: Temperature and accumulation of high altitude firn in the Alps, Ann. Glaciol., 6, 161-163, 1985.

Haeberli, W. and Funk, M.: Borehole temperatures at the Colle Gnifetti core-drilling site (Monte Rosa, Swiss Alps), J. Glaciol., 37, 37-46, 1991.

Harrison, W. D.: Temperatures of a temperate glacier, J. Glaciol., 11, 15-29, 1972.

Humphrey, N.: Estimating ice temperature from short records in thermally distributed boreholes, J. Glaciol., 37, 414-419, 1991.

Lachenbruch, A. and Brewer, M.: Dissipation of the temperature effect of drilling a well in Arctic Alaska, US Geological Survey Bulletin, 1083-C, 73-109, 1959.

Laternser, M.: Firntemperaturen in den Schweizer Alpen, MSc thesis, ETH-Zürich, 1992.

Lliboutry, L., Briat, M., Creseveur, M., and Pourchet, M.: $15 \mathrm{~m}$ deep temperatures in the glacier of Mont Blanc (French Alps), J. Glaciol., 16, 197-203, 1976.

Lüthi, M. P. and Funk, M.: Wie stabil ist der Hängegletscher am
Eiger, Spektrum der Wissenschaft, 5, 21-24, 1997.

Lüthi, M. P. and Funk, M.: Dating ice cores from a high Alpine galcier with a flow model for cold firn, Ann. Glaciol., 31, 69-79, 2000.

Lüthi, M. P.: Rheology of cold firn and dynamics of a polythermal ice stream. Studies on Colle Gnifetti and Jakobshavns Isbrae PhD thesis, ETH Zürich, 2000.

Lüthi, M. P. and Funk, M.: Modelling heat flow in a cold, high altitude glacier: interpretation of measurements from Colle Gnifetti, Swiss Alps, J. Glaciol., 47, 314-324, 2001.

Müller, F.: Zonation in the accumulation area of the glaciers of Axel Heiberg Island, N.W.T., Canada, J. Glaciol., 4(33), 123135, 1962.

Noetzli, J., Gruber, S., Kohl, T., Salzmann, N., and Haeberli, W.: Three-dimensional distribution and evolution of permafrost temperatures in idealized high-mountain topography, J. Geophys. Res., 112(F02S13), doi10.1029/2006JF000545, 2007.

Noetzli, J. and Gruber, S.: Transient thermal effects in Alpine permafrost, The Cryosphere, 3, 85-99, doi:10.5194/tc-3-85-2009, 2009.

Oeschger, H., Schotterer, U., Stauffer, B., Haeberli, W., and Röthlisberger, H.: First results from Alpine core drilling projects. Zeitschrift für Gletscherkunde und Glazialgeologie, 13, 193208, 1977.

Paterson, W. S. B.: The Physics of Glaciers, 3 Edn., Pergamon Press Ltd., 380, 1994.

Schwerzmann, A.: Borehole analyses and flow modelling of firncovered cold glaciers, PhD thesis ETH Zürich, 2006.

Shumskii, P. A.: Principles of structural glaciology, Dover Publications, Inc., New York, 497, 1964.

Suter, S.: Die Verbreitung kalter Firn- und Eisregionen im Alpengebiet, MSc, ETH Zürich, 1995.

Suter, S.: Cold firn and ice in the Monte Rosa and Mont Blanc areas: spatial occurrence, surface energy balance and climatic evidence, $\mathrm{PhD}$ thesis, ETH Zürich, 2002.

Suter, S. and Hoelzle, M.: Cold firn in the Mont Blanc and Monte Rosa areas, European Alps: spatial distribution and statistical models, Ann. Glaciol., 35, 9-18, 2002.

Suter, S. and Hoelzle, M.: Kalte Gletscher als PalŁotemperaturarchiv - Untersuchungen aus dem Mont-Blanc- und Monte-RosaGebiet. Vierteljahresschrift der Naturforschenden Gesellschaft in Zürich, 149, 95-104, 2004.

Suter, S., Hoelzle, M., and Ohmura, A.: Energy balance at a cold, alpine firn saddle, Seserjoch, Monte Rosa, Int. J. Climatol.,, 24, 1423-1442, 2004.

Suter, S., Laternser, M., Haeberli, W., Frauenfelder, R., and Hoelzle, M.: Cold firn and ice of high-altitude glaciers in the Alps: measurements and distribution modelling, J. Glaciol., 47, 85-96, 2001.

Vallot, J.: Recherches scientifiques dans le tunnel du MontBlanc. Annales de l'Observatoires Météorologiques, Physique et Glaciaire du Mont-Blanc, 1, 131-143, 1893.

Vallot, J.: Valeur et variation de la temperature profonde du glacier, au Mont Blanc, Comptes Rendus Hebdomadaires des Séances de l'Académie des Sciences, 20, 1575-1578, 1913.

Vincent, C., Vallon, M., Pinglot, J.F., Funk, M., and Reynaud, L.: Snow accumulation and ice flow at Dome du Gouter $(4300 \mathrm{~m})$, Mont Blanc, French Alps, J. Glaciol., 43, 513-521, 1997.

Vincent, C., Le Meur, E., Six, D., Funk, M., Hoelzle, M., and Pre- 
unkert, S.: Very high-elevation Mont Blanc glaciated areas not affected by the 20th Century climate change, J. Geophys. Res., 112, D09120, doi:10.1029/2006JD007407, 2007a.

Vincent, C., Le Meur, E., Six, D., Possenti, E., Lefebre, F., and Funk, M.: Climate warming revealed by englacial temperatures at Col du Dme (4250 m, Mont Blanc area), Geophys. Res. Lett., 34, L16502, 5 pp., doi:10.1029/2007GL029933, 2007 b.
Wagner, S. Dreidimensionale Modellierung zweier Gletscher und Deformationsanalyse von eisreichem Permafrost, PhD thesis, ETH Zürich, 1996.

Wegmann, M., Gudmundsson, G. H., and Haeberli, W.: Permafrost changes in rock walls and the retreat of Alpine glaciers: a thermal modelling approach, Permafrost Periglac., 9, 23-33, 1998.

Zotikov, I. A.: The thermophysics of glaciers, Reindel Publ., 275, 1986. 